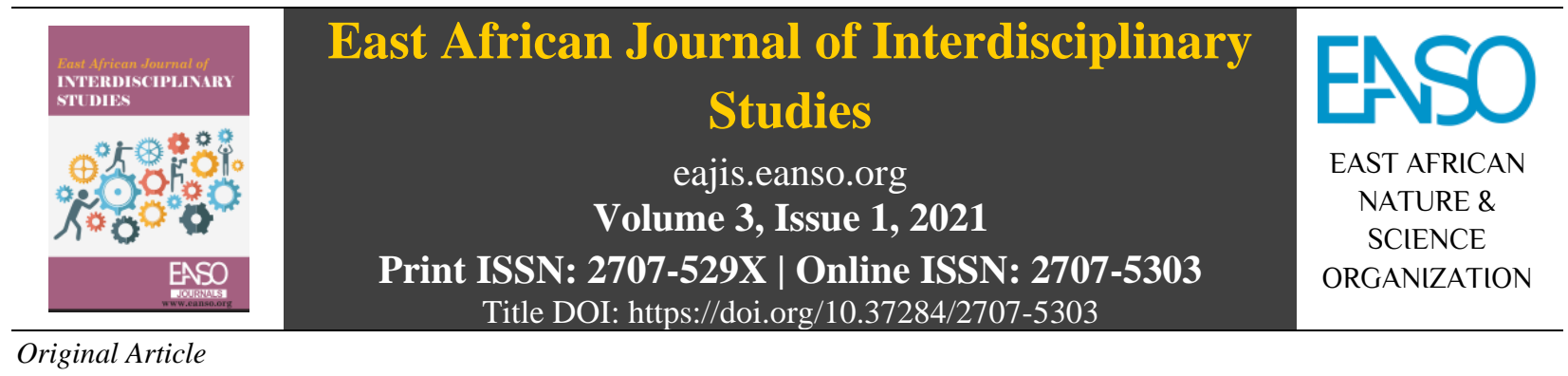

\title{
An Iconic Pillar of Hope in a Rural Township: The Emergence, Growth and Development of AIC Kapsowar Mission Hospital
}

\author{
Nelson Amdany Kiptoo ${ }^{* 1}$, Dr. Dorothy Nyakwaka, PhD ${ }^{1} \&$ Dr. Isaac Tarus, PhD ${ }^{1}$ \\ ${ }^{1}$ Egerton University, P. O. Box 536, Egerton, Kenya. \\ * ORCID: https://orcid.org/0000-0002-4591-1153; Author for Correspondence Email: snrkiptoo.nk@ gmail.com
}

Article DOI: https://doi.org/10.37284/eajis.3.1.390

\section{Date Published: ABSTRACT}

20 August 2021 The article is about the emergence, growth and development of AIC Kapsowar Mission Hospital, the hospital that was central to the development of Kapsowar town

Keywords: $\quad$ since its establishment in 1934. The hospital was so iconic in the sense that it opened Marakwet District to the rest of the world. The hospital created employment Pillar of Hope, opportunities for Kenyans who flocked the town in their thousands in search of jobs. Rural Kapsowar which was once a frontier town transformed into a medical town making Tisplay many signs of prosperity. However, it was not easy for the Africans living Township, in Kapsowar to let go of their lands. They had to fight back and protect what according AIC Kapsowar to them was given to them by their deity ASIS. Among the Marakwet, land was Mission communally owned and its use was decided by the community elders. Individuals did Hospital. not own land as the sole owners but the land was in the custody of clans. This factor made it very hard for the missionaries to acquire land to establish the mission hospital when they first arrived at the place. The locals were only convinced after a series of successful surgeries were conducted by the mission doctors and that was when they allowed them to settle in their land. That move marked the beginning of a new civilisation among the Marakwet. Many women began to visit the hospital for child delivery, and child mortality rate reduced drastically owing to the good works of the mission doctors. All the good things brought about by the mission Hospital including the development of the town, employment opportunities, improved infrastructure among others notwithstanding, challenges never seized to hit the Mission hospital and the latest challenge was posed by the outbreak of the novel corona virus in 2020 causing a lot of fear and panic to both the doctors and the patients.

\section{APA CITATION}

Kiptoo, N. A., Nyakwaka, D., \& Tarus, I. (2021). An Iconic Pillar of Hope in a Rural Township: The Emergence, Growth and Development of AIC Kapsowar Mission Hospital East African Journal of Interdisciplinary Studies, 3(1), 186-194. https://doi.org/10.37284/eajis.3.1.390.

\section{CHICAGO CITATION}

Kiptoo, Nelson Amdany, Dorothy Nyakwaka, and Isaac Tarus. 2021. "An Iconic Pillar of Hope in a Rural Township: The Emergence, Growth and Development of AIC Kapsowar Mission Hospital”. East African Journal of Interdisciplinary Studies 3 (1), 186-194. https://doi.org/10.37284/eajis.3.1. 390.

186 This work is licensed under a Creative Commons Attribution 4.0 International License. 


\section{HARVARD CITATION}

Kiptoo, N. A., Nyakwaka, D., and Tarus, I. (2021) "An Iconic Pillar of Hope in a Rural Township: The Emergence, Growth and Development of AIC Kapsowar Mission Hospital”, East African Journal of Interdisciplinary Studies, 3(1), pp. 186-194. doi: 10.37284/eajis.3.1.390.

\section{IEEE CITATION}

N. A. Kiptoo, D. Nyakwaka, and I. Tarus, "An Iconic Pillar of Hope in a Rural Township: The Emergence, Growth and Development of AIC Kapsowar Mission Hospital”, EAJIS, vol. 3, no. 1, pp. 186-194, Aug. 2021.

\section{MLA CITATION}

Kiptoo, Nelson Amdany, Dorothy Nyakwaka, and Isaac Tarus. "An Iconic Pillar of Hope in a Rural Township: The Emergence, Growth and Development of AIC Kapsowar Mission Hospital”. East African Journal of Interdisciplinary Studies, Vol. 3, no. 1, Aug. 2021, pp. 186-194, doi:10.37284/eajis.3.1.390.

\section{INTRODUCTION}

The establishment of Kapsowar mission hospital dates back to 1934. Kibor observes that as late as 1930, the District Commissioner in the then Marakwet District indicated that there were no missions working in the district. According to him, towards the close of 1930, two catholic fathers named Hartmann and Bergman visited the government school at Tambach the then District headquarters, and conferred with the principal regarding the possibility of attaching to the school a Christian (Roman Catholic) native who would give religious instructions to those who desired. Consequently, a native catechist was sent from the Roman school at Eldoret in 1931 (Kibor, 2005)

Kibor further argues that in 1931 Reverend Reynolds of AIM Kapsabet accompanied by Abraham Rurie of Githumu, visited Tambach and Marakwet with a view of inaugurating mission work in the field. Later in the same year, the mission sent two native adherents from Kapsabet on a short trip to Marakwet to spy out the land. By then, the government was moving its outpost station from Kapsowar to Tambach. The mission therefore, moved with speed and arranged with the District Commissioner to purchase the old government land at Kapsowar. This was estimated to be around thirty acres (Ibid).

The Colonial government upon closing the colonial administrative post and handing it over to A.I.M Mission, the hospital would be the goal. A.I.M had three goals to establish, a church, a School and a hospital which was in line with the government and the people of Marakwet. The medical work was started in November 1933 by Bessie Mildenhall who was a nurse. Kibor, observes that he dedication ceremony was done on 19th October 1934 by Mr. Harry Lunn a farmer in Laborate in the current Uasin Gishu County and a member of Home \& Field council of A.I.M in the presents of the colonial D.C Mr. Llewelyn, Reg \& Zan Reynolds, Bessie Mildenhall the nurse, Leigh Ashton, Frances collier, and Rev \&Mrs Stuart Bryson. Mr. Laurie Walker a business man and Chairman of the London Council, was to lay the foundation stone of the hospital but took ill on his way coming and died and was buried in Mombasa and because of his dedication to the project, the Hospital was called Laurie Walker Memorial Hospital until the AIC took over in 1952 (Kibor, 2005) Edwin concluded that Lord had been so faithful to the works that were started by Laurie and the team.

Edwin, a reverend at Kapsowar AIC posits that the beginning of missionary in Marakwet faced a lot of challenges. The main challenge according to him came, from some Muslim faithful like Ibrahim Alli who owned a shop next to the station. He further argues that Ibrahim staged a considerable amount of resistance to the missionaries. He went ahead to tell the locals how dangerous it was to allow missionaries to settle in their land, to him, the missionaries settling in there could only mean that they would be deprived of their sons. (Edwin, OI, 12/06/2021) alleges that a prayer contest was conducted and the main aim was to challenge Ibrahim a Somali Muslim. According to him, their prayers were answered by God because after the contest, Ibrahim died after three days. And the missionaries went ahead to purchase the land as was the earlier plan, the few structures that were left behind were used as a dispensary as the missionaries were planning for future improvements (Edwin, OI, $12 / 06 / 2021)$. 


\section{Post-Colonial growth of AIC Kapsowar Hospital}

After Kenya had obtained her independence from the colonisers, most of the projects that were initiated by the colonial government were taken over by the government. Kapsowar Mission Hospital was not an exemption. Though being under AIM, the government played a key in enhancing its development. In 1964 for instance, the government came in handy to appreciate the magnificent efforts made by the missions and missionaries in the field of health services, and they were praised by the
Minister for Health and Housing, Dr. Mungai, when he opened a new male ward and nurses' home at Kapsowar Hospital in the Elgeyo-Marakwet district. The government agreed to give the hospital grants of up to 50 percent of the capital for expenditure. The grant went a long way in helping the hospital management to construct a mortuary and the laundry section. At the same time, a concrete path was laid, joining the men's and women's wards at the lower level, with steps down to the Laundry/Kitchen block which had a concrete surround to it (KNA, 1964, Chelugoi, OI, 24 June, 2021)

Figure 1: Photograph showing Kenya's Minister for Health Dr. Mungai, opening the new male ward and nurses' home at Kapsowar Hospital in 1964.

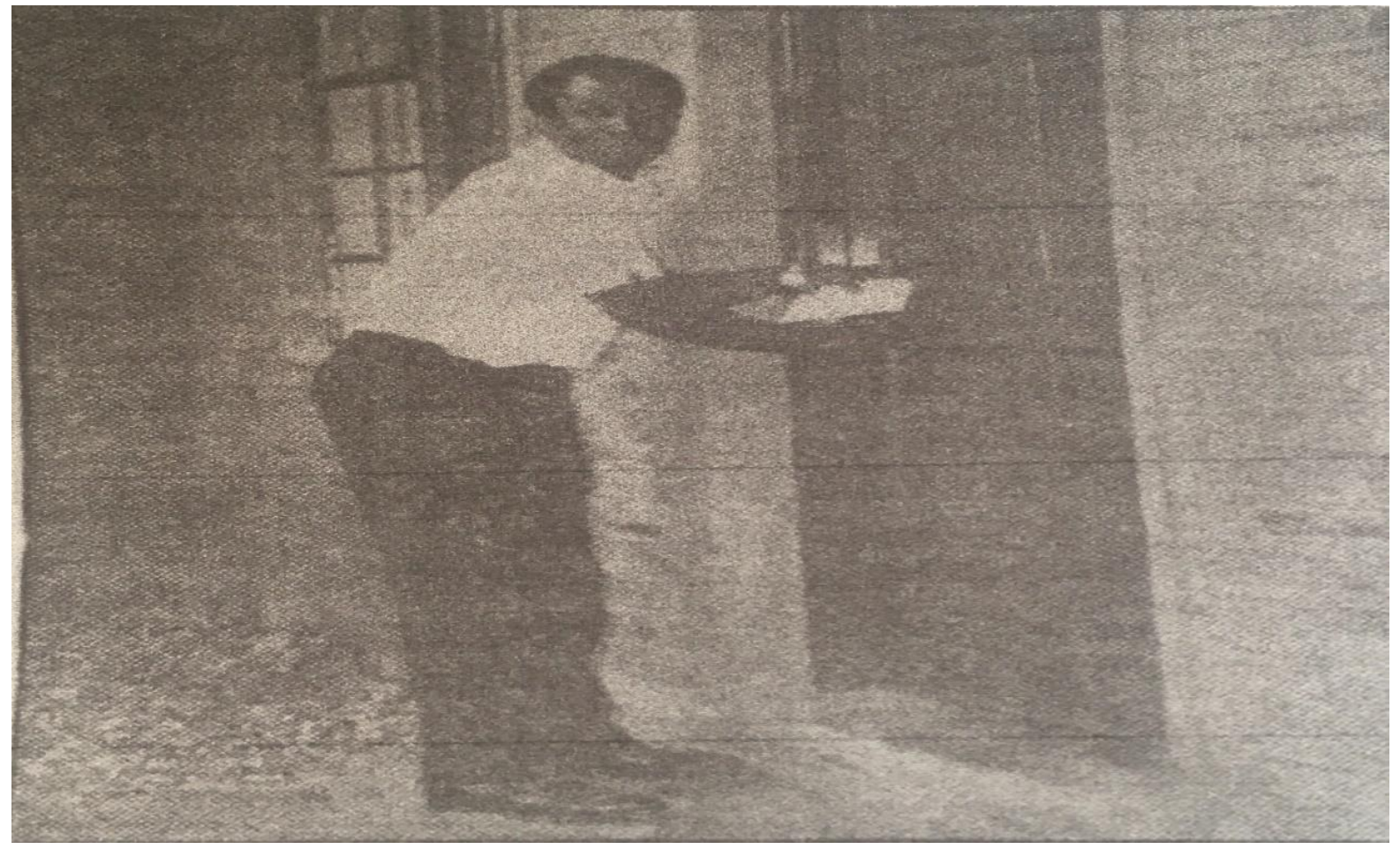

Source: Kenya National Archives

The Hospital electric circuits had then been reorganised, being centred on the theatre where the power line from the X-ray generator joined the main station circuit. The area in front of the hospital had been enclosed and parking facilities were provided on the upper approach road. A motor mower had been purchased with a gift from England as more grass was enclosed as the area of the hospital expanded. Latrines had been built, the inside walls of the dresser's houses had been cemented, there were improved sink and sluicing facilities in wards. Plans were also underway to construct a children's ward to replace the old condemned Nurses Home and a private wing which would go a long way to provide a better type accommodation for those benefiting under the HHIF (KNA, 1964)

188| This work is licensed under a Creative Commons Attribution 4.0 International License. 
Figure 2: Photograph showing Dr. Mungai and Dr. R.S Lindsay talking to women patients at Kapsowar AIM Hospital when he opened a new men's ward in 1964

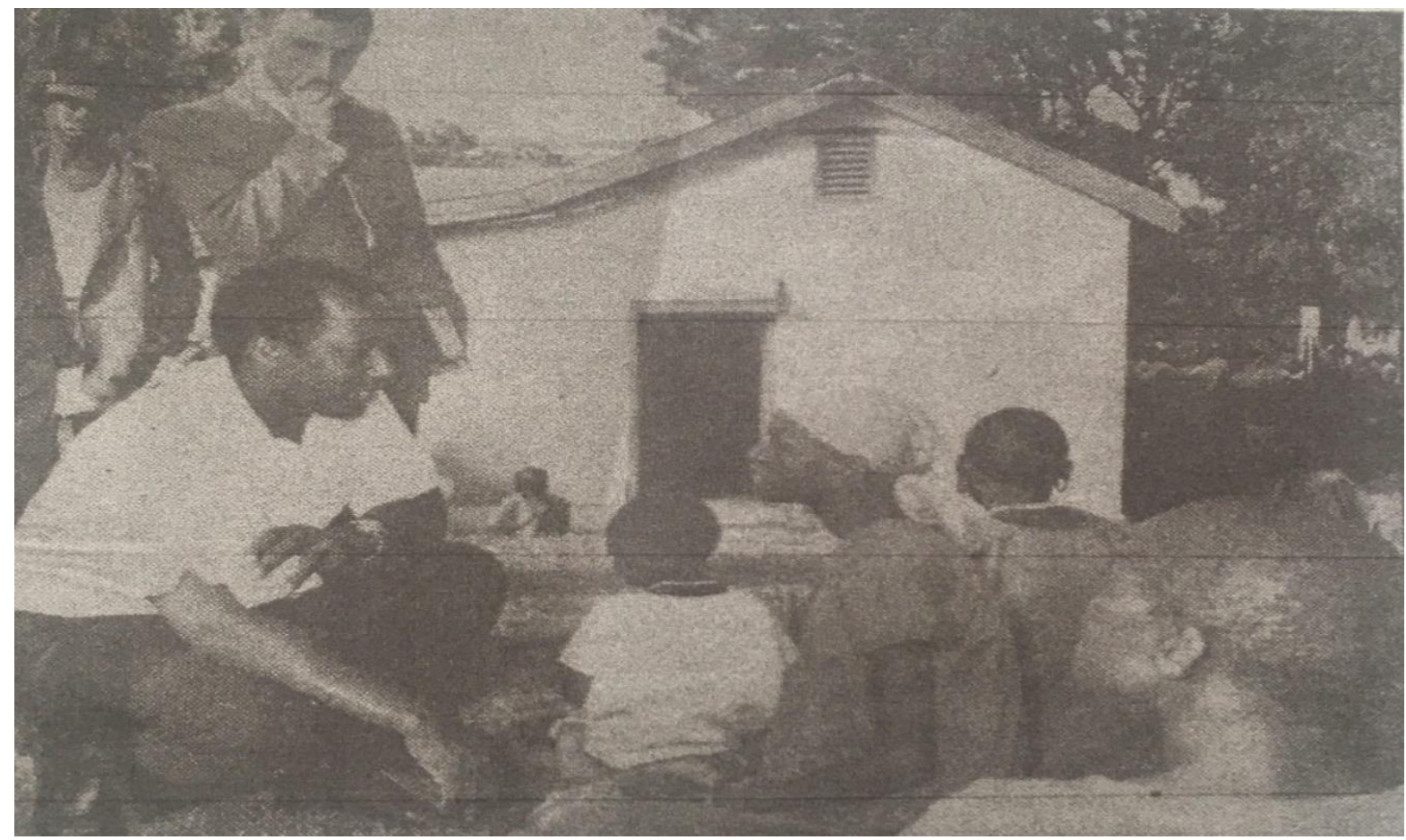

Source: Kenya National Archives

In 1967 , there was an 18 percent increase in the work load of the hospital, as was evidenced by the increase in the number of patients admitted to the wards. In addition to the hospital, there was a regular visitation and supervision of the four dispensaries. A fifth at Liter was run by a missionary nurse and was also visited monthly by the doctor. There had been repeated requests for the hospital to reopen the other two Dispensaries which had to be closed in the previous years. The County council came in handy to help in the reopening of the two Dispensaries hence a further boost to the development of the hospital. The success of the ante-natal clinic had also been shown by the further rise in 1967 in the number of maternity cases. In addition to the Tuberculosis (TB) and child welfare clinics, a start was made with a family planning clinic (Ibid, p. 3)

1968 was a year of considerable expansion for Kapsowar Hospital exceeding the expectations that were in place. As soon as approval of the plan for the children's ward was received in January the work of construction was begun. The foundation stone was laid by His Excellency, the Vice-
President of Kenya on 9th February. After completion the ward opened on 8th June by the Director of Medical Services, Dr. J. C. Likimani. Since then, the ward had been constantly full. Approval of the plan for the Dormitory annexe to the Nurses' Home was not received until later in the year. Despite some setbacks work went ahead well and it too was ready for the opening ceremony on $8^{\text {th }}$ June. The furnishing took rather longer to complete (Ibid)

The third project completed in the financial year $1967 / 68$ was the new kitchen for the Nurses' Home. It proved unsuitable to have the kitchen included in the main building and the addition of an Alfa Laval cooker had enhanced the facilities. For 1968/69 the Hospital management embarked upon two further projects, one of which, an Enrolled Nurses' Staff House, had already been completed. The construction of the twenty-thousand-gallon water storage tank had been shelved. Steady work had also been carried out by the garden staff to improve the appearance of the hospital surrounding and the planting of trees-Aracaria, Eucalyptus and Pine which added beauty to the facility (Ibid)

189| This work is licensed under a Creative Commons Attribution 4.0 International License. 
The Moi family became part and parcel of the Hospital and the Church at large. Moi learnt about the Hospital and the Church in Kapsowar when he was still a teacher at Tambach. Chebelion observes that Lena Moi was equally a frequent visitor of the facility. Lena Moi could be taken to the facility whenever she was ill. The relationship between the Moi family and the Hospital and even the Church grew so strong to an extent that Moi could preside over a lot of Harambee that was conducted by the hospital. Chebelion further argues that the relationship even became stronger when Moi was elevated to the post of presidency in 1978. To him, when Moi became the second president the development of the hospital became so rapid because Moi always made resources available. The love that Moi and the family was very important as it opened up the hospital to the rest of the country and globally. The current status of the Hospital could not be achieved if it were not for the intervention of Moi Chebelion explained (Oral Interview, Chebelion, 60 years Old, 20, July 2021). Mutwol on his part argued Moi became a very strong pillar to the Hospital and the Church. His support was so overwhelming. According to him, Moi supported the facility even after retiring from active politics in 2002 (Oral Interview, Mutwol, 52 years Old, 24, September 2021).

When the new regime took office, there was a lot of fear that the hospital would never receive resources as it used to when the benefactor was in power. The fact that Moi was not in power never stopped him from supporting the hospital. His generous support continued as was before. The next hope was being built on the new constitution which began to take shape when the new government took office. The new constitution which was promulgated in 2010 advocated for the devolved system of government. This meant that governments would be brought to the grassroots level. This move made the Hospital management have hope that the County government would also cheap in to inject more resources just like what Moi used to do while in power (Oral Interview, 55 years Old, 13, August 2021).

\section{Figure 3: AIC Kapsowar Mission Hospital}

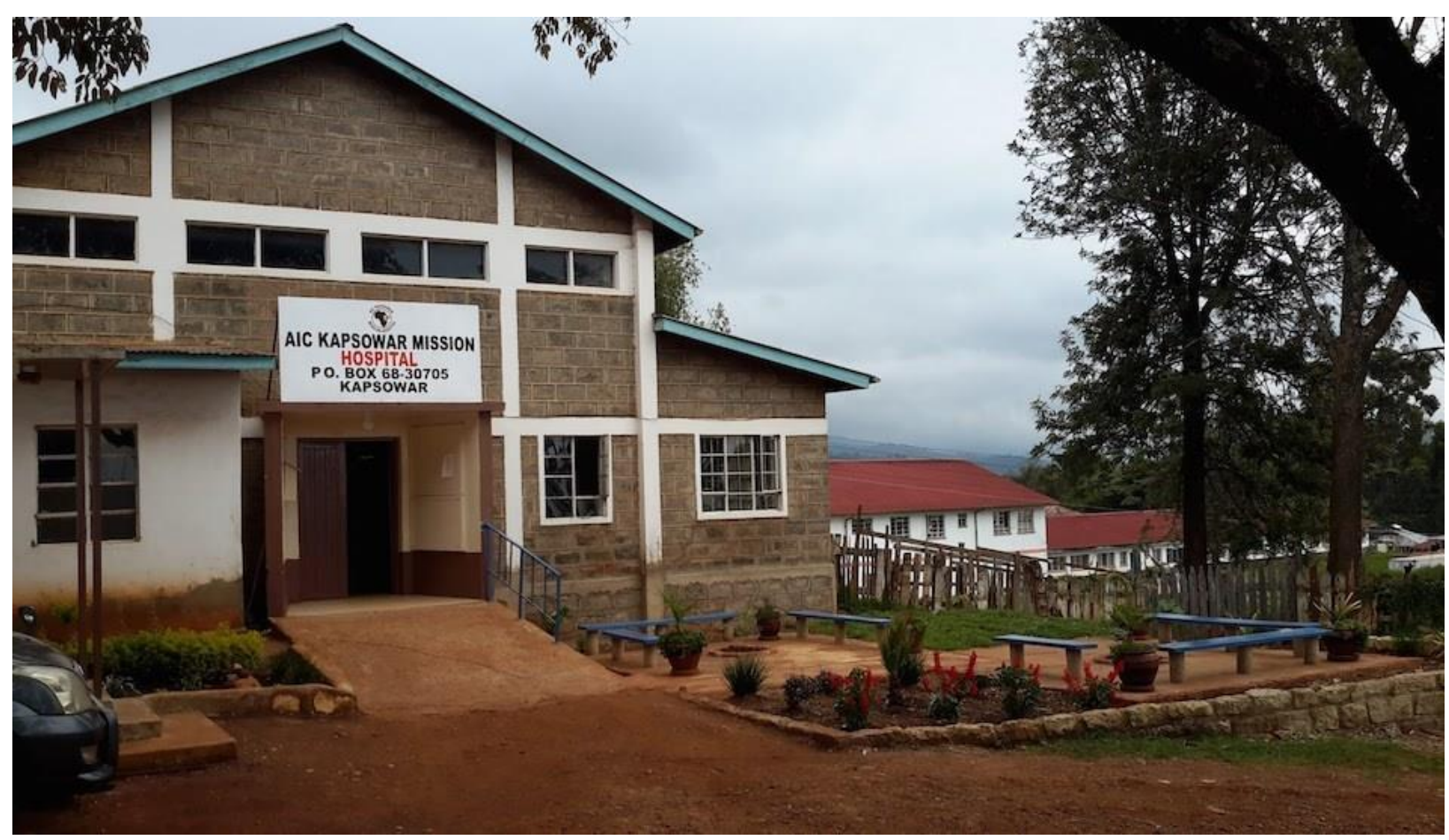

Source: Photograph taken by the Author.

190| This work is licensed under a Creative Commons Attribution 4.0 International License. 


\section{AIC Kapsowar Hospital and The Growth of Kapsowar town}

Chepkemoi, a long-time farmer nostalgically informed the study that the town began as a small trading agricultural centre. It is one of the fastgrowing towns in Elgeyo Marakwet. The growth of Kapsowar has been supported by the establishment of the mission Hospital. The town began as a meeting point for traders who assembled their products for transportation to bigger towns like Eldoret, Nakuru, and Nairobi (Oral Interview, Chepkemoi, 75 years Old, 13 August 2021). It was initially a temporary housing area with few structures which just acted as stores for the farm produce. As the produce from the farm increased, the centre also had an upward trajectory as the farmers needed more space for goods storage.

Koech, who is also a retired teacher argues that the availability of the mission hospital was the main reason why people chose Kapsowar to be the trading location. This was because of good health. The hospital provided better health care services to the people of Kapsowar and its services attracted people from far and wide. It was observed that Kapsowar grew rapidly due to the availability of a modern health facility. It was easy to put up shops because the population was steadily increasing and that only meant that the demand for goods was equally high (Oral Interview, Koech, 73 years Old, 12, July, 2021).

As the small structures advanced to better houses and many people joined the trade, the government had to step in to set records straight. The centre was subdivided into plots by the County Council of Elgeyo Marakwet and the inhabitants were allocated plots to develop (KNA/DC/MAR/16/201/2, Annual Reports, 1970). During the plot allocation of course some members from the highlands may have infiltrated the system but most owners were the inhabitants of Kapsowar. The majority numbers of the people occupying the town are Kikuyu, Tugen, Pokot, Turkana, and Kipsigis. Their existence in the town is closely linked to the existence and growth of the hospital. Kapsowar town has taken time to grow and attain its status as it is now. The structures are mostly semi-permanent with a few permanent structures. The planning of the town is well organised and the market place is located near the road to make it easily accessible and convenient for the traders. According to Kipkanyilak, the town was planned with the close supervision of the provincial administration who wanted to have a clean, wellplanned town in the future (Oral Interview, Kipkanyilak, 93 years Old, 29 July 2021).

The administrators made it their duty to constantly check on the upcoming houses and other infrastructures within the town. There are feeder roads which have been opened up in the town to allow faster movement within the town and efficient supply of goods and services to the traders. Although most of these roads have been encroached on, they were put in place to facilitate easier access to the interior of the town especially during emergencies like fire breakouts. The necessary amenities for the traders have been strategically placed for them to enjoy the town and invest in it more as it is attractive and reasonable to move around (Oral Interview, Kimuge, 57 years Old, 12 June 2021).

The growth of Kapsowar town necessitated the establishment of rental residences. People needed decent houses to settle in as they worked in the hospital. The town experienced new houses for the increasing population. Good rental houses were put up by traders and the missionaries. There was population increase in the town and people sought better houses to rent and live in. Arguably, with the advancement of in houses, sanitation became a problem. The population increase meant many houses and the area was not properly planned so waste disposal became a problem. The town therefore, had to be re-planned for better living conditions.

The hospital employs many of the area residents. These labourers come from far places. These employees work in the hospital from morning to evening and they settle down for the night. The town has acted as a residential area for them since they started working in the hospital. Kenya Power has also set up a power substation at Kapsowar. This has helped boost the growth of the town as businesses are assured of electricity supply all the time. The offices are within the town and so in case of any problem it is easy to rectify and sort out. It takes a shorter time unlike in the past times when the locals had to travel to Tambach town for their electricity 
to be sorted. The town is well light at night and thus cases of insecurity are minimal. The police station set up in town also acts as a good security provider and promotes the growth of the town. Hospital workers and traders are assured of security.

\section{Figure 4: Kapsowar town}

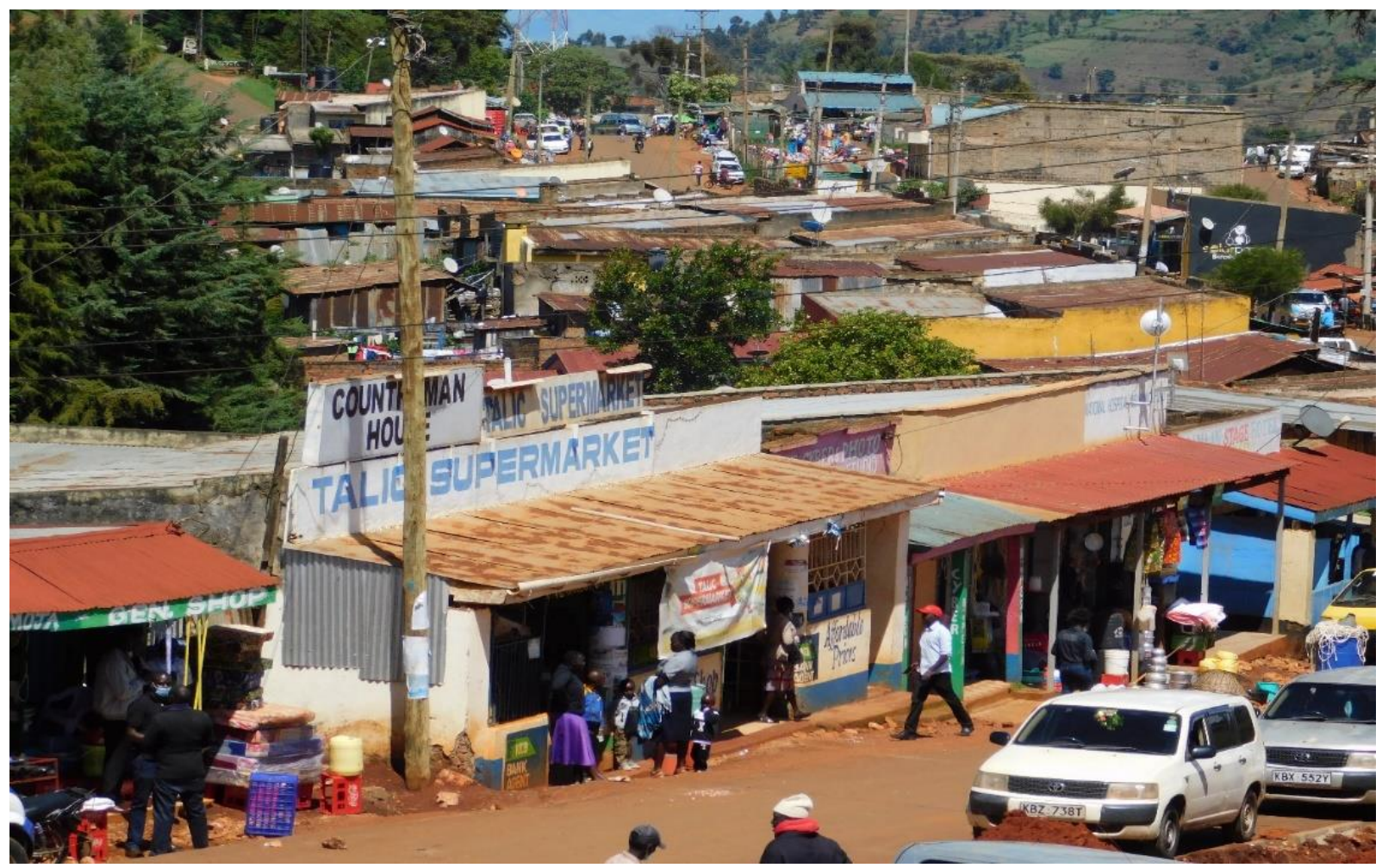

Source: Photograph taken by the author

\section{Challenges Experienced by the Mission Hospital}

The worst of all in the relationship between the missionaries and the locals according to Rae, was that each assumed their way of life was better than any other. The newcomers hardly questioned the rightness of sharing, not only the Christian religion, but also the assumed benefits of their western civilisation. Notably, missionaries differed from the officials over numerous issues but where the missionary found the African customs wicked, the government administrator found them a barrier to progress, and in breaking down their solidarity the administrator saw the missionary as his ally (Rae, 1969)

Far from cultural superiority, the AIC Kapsowar mission has experienced a lot of challenges even after existing for close to a century. To begin with, Infrastructure is the basic facilities and installations needed for the functioning of an establishment. These are the main facilities that keep the facility running and ensure it achieves its results as expected by funders. These may include roads and buildings that the hospital heavily relies on. Most of the infrastructure in the town are out of service as the few others are not enough or able to handle the demand of the hospital. Mutwol, who is also the director of the hospital observes that the hospital is aged, according to him most of the structures that are existing were built in 1934 and they have lost strength despite the repairs that have been done on them over time. The poor and weak structures make the hospital less attractive especially for the inpatients. Mutwol, further argues that if they are not careful, the chances of some of their structures collapsing was very high (Oral Interview, Mutwol, 52 Years Old, 21, June, 2021).

192| This work is licensed under a Creative Commons Attribution 4.0 International License. 
Machinery in the Hospital requires servicing and maintenance every time. The cost of maintaining the machines is very expensive and all the expenses are taken care of by the hospital. Most of the time the machines require spare parts which are not available in the local market. These spare parts are imported at the cost of hospital management which is very costly. But the hospital's operations have to run and they are then forced to undertake these measures. The few machines are hired from other private firms like Kijabe which is the biggest AIM Mission Hospital in Kenya. It is thus noted that the hospital management and daily running is a costly affair. It takes the hospital management time before they recover the costs which they incur in maintenance and operations. It is a practice by the employees of the Hospital to try and help the Hospital run smoothly in a cost- friendly way but since most of the operations require finances it is hard for the costs to come down. Notably, the high cost of operations and maintenance is one big challenge to Kapsowar mission Hospital which can bring it to nonoperational status if not well checked and managed (Oral Interview, Mutwol, 52 years Old, 21, June, 2021).

Mutwol, emotionally told that financial crisis is also another night mare that the hospital has had in the past years. To him, this crisis is both real and manmade. He told regrettably that the man-made financial crisis is caused by a few officials in the National Hospital Insurance Fund (NHIF) offices who have refused to release the money for the mission hospital. He further argued that NHIF was owing the Hospital three months payroll during the time of the study, a move that according to him caused delays in staff salaries. Kapsowar mission Hospital being a referral Hospital, it receives patients from far and wide, their priority is to offer quality healthcare services to everyone who visits their facility. However, most of the patients do not pay for the services rendered to them especially those without NHIF, some cases are genuine but some are not genuine and those are the real financial crisis according to Mutwol. "The hospital records around ten to fifteen million unpaid debts from cash without including the debts from NHIF" he further explains (Oral Interview, Mutwol, 52 years Old, 21, June, 2021).
Exploitation from the County government revenue collector and the tax man. In as much as the hospital has a very good relationship with the County government of Elgeyo Marakwet, there is very insignificant support that the hospital receives from the County government and the national government. The hospital has suffered from heavy taxing which according to the management is pure exploitation. Mutwol, told me emotionally that the facility has over twenty licenses which they are paying for very expensively including NEMA license, business permit, County government permit among others. Most of the taxes that the hospital was forced to pay were not witnessed in other public hospitals. In other words, in as much as the hospital was trying to play its missionary roles, the tax collectors saw it as the best spot the earn more from (Ibid)

A mass exodus of staff has also been another main challenge that the hospital has faced for years. As a mission Hospital, their main aim was to provide quality healthcare services to the people without expecting any payment in return. Missionaries believed that payment only comes from God. This was a fact that most of the Hospital staff refused to live with. Due to the hard economic times most of the staff preferred to look for other Hospitals public or private where their needs could be addressed to their satisfaction. This move widened the ratio between the doctors and the patients. Some informants told jokingly that in the society we live in today, youths are yearning for quick wealth, patience was no longer part of them. They went ahead to argue that a young doctor is hired for instance today then in less than a year, they want to drive high-end cars. The hospital was not in a position to maintain doctors with such desires and that was why the mass exodus was being witnessed (Oral Interview, Barchok, 35 years Old, 10, July 2021).

When COVID-19 hit the country in 2020, there was a lot of panics especially among the healthcare providers. Being a new deadly virus, everyone feared and doctors were no exemption. Kapsowar residents were equally worried and they never knew how they would go about the virus. Since the County government did not have any better site for isolation, AIC Kapsowar Mission hospital had to create an isolation place for the COVID-19 patients.

193 This work is licensed under a Creative Commons Attribution 4.0 International License. 
Mutwol, argues that the County government only supplied the facility with the testing kits and nothing more to it. According to him, the number of patients visiting the facility reduced drastically because people feared interacting with doctors. The drastic drop in the number of patients visiting the facility only meant a reduction in revenues which almost made the running of day-to-day activities of the hospital almost impossible. Despite all the challenges, the hospital still managed to take care of the COVID-19 patients without any discrimination. Mutwol, concluded by observing that they only lost one patient to COVID-19 (Oral Interview, Mutwol, 52 years Old, 23, July 2021).

\section{CONCLUSION}

Kapsowar Mission Hospital was established in Kapsowar District with the aim of changing the lives of the Marakwet. As the only level five hospital in the whole of Elgeyo-Marakwet county, it has served patients not only within the county but from far and wide. The fact that the hospital serves people without boundaries does not mean it is not struggling financially. This is a factor that even the county government has failed to comprehend. When the hospital is well funded, its operations will continue hence its growth. When that happens, the town also grows and it becomes a win-win growth. It is therefore prudent for the county government of Elgeyo-Marakwet to rise up from its slumber bed and support AIC Kapsowar Mission Hospital unconditionally. The mission hospital has a long history and it reminds the people of Marakwet of the good intentions that the missionaries had for them, their resistance from the start notwithstanding.

\section{REFERENCES}

Kibor, J. Z. (2005). The growth and development of the Africa Inland Mission and Africa Inland Church in Marakwet, Kenya. African Journal of Evangelical Theology, 24, 107-128.

KNA, 1964; Chelugoi, OI, 24 June, 2021

KNA/DC/MAR/16/201/2, Annual Reports, 1970.

Rae, J. G. (1969). A historical study of the educational work of the Africa Inland Mission in Kenya, 1969: Afr. MFM 1981/218 (Doctoral dissertation, University of Nairobi) 